\title{
Hidden and Uncontrolled Hypertension Leading Aortic Dissection
}

\section{Aort Diseksiyonuna Neden Olan Gizli ve Kontrolsüz Hipertansiyon}

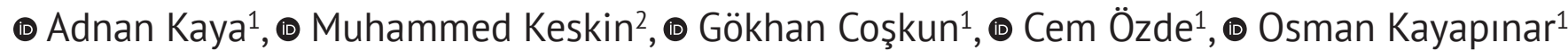 \\ ${ }^{1}$ Düzce University Faculty of Medicine, Department of Cardiology, Düzce, Turkey \\ ${ }^{2}$ University of Health Sciences Turkey, Istanbul Sultan 2. Abdülhamid Han Training and Research Hospital, Clinic of Cardiology, Istanbul, Turkey
}

Aortic dissection (AD) is one of the most devastating acute cardiovascular disorders and commonly occurs in patients with underlying aortic dilatation and connective tissue disorders such as Marfan syndrome and vascular type Ehlers-Danlos syndrome. In this report, we present a patient whose AD occurred in a normal aortic dimension due to underlying long-lasting, hidden and uncontrolled hypertension.

Keywords: Aortic dissection, left ventricular hypertrophy, hypertension

Aort diseksiyonu (AD) en tehlikeli akut kardiyovasküler hastalıklardan biri olup genellikle altta yatan aort dilatasyonu ve Marfan sendromu, vasküler tip Ehler-Danlos sendromu olan hastalarda gelişir. Bu yazıda normal aort çapına rağmen gizli, uzun süren ve kontrolsüz hipertansiyona bağlı olarak AD gelişen bir hastayı sunmaktayız.

Anahtar Kelimeler: Aort diseksiyonu, sol ventrikül hipertrofisi, hipertansiyon

\section{Introduction}

High blood pressure (BP), which is estimated to be seen in $30-45 \%$ of adults, is one of the most important reasons for cardiovascular mortality (1). It brings about an increased cumulative cardiovascular risk (hemorrhagic stroke, ischemic stroke, myocardial infarction, sudden death, heart failure, and peripheral artery disease) and end stage renal disease if untreated (2). Hypertension-mediated organ damage (HMOD), which means structural or functional changes in arteries or end organs (heart, blood vessels, brain, eyes, and kidney), caused by an elevated BP is a marker of pre-clinical or asymptomatic cardiovascular disease (3). Some types of HMOD can be reversed by antihypertensive treatment, especially when treated early, but with long-standing hypertension, HMOD may become irreversible despite improved BP control (4). Left ventricle hypertrophy, HMOD of the heart, could not be regressed or stopped despite diagnosed and treated timely. Approximately $1 \%$ of the hypertensive patients encounter with serious hypertensive urgency and/or hypertensive emergency (5). One of these hypertensive urgencies is aortic dissection (AD), which is one the most serious acute cardiovascular situations. The incidence of $A D$ is $3 / 100,000$ every year and most of these patients have a diagnosis of hypertension before the incident and this complication is commonly encountered in patients aged over 50 years $(6,7)$. Some predictors of death in AD are hypotension, cardiogenic shock, pericardial tamponade, acute kidney failure, age $>70$-year, sudden onset of chest pain and abnormal changes in electrocardiography $(8,9)$. Therefore, $A D$ is rarely seen in young patients and newly diagnosed with hypertension. By presenting this case, we would like to demonstrate what a strengthened (thickened) left ventricle and long-lasting uncontrolled hypertension are capable to; an AD.

\section{Case Report}

A 54-year-old lady was brought to our emergency department (ED) by 112 ambulance due to syncope and chest pain that occurred while she was cleaning her bathroom. Her family

Address for Correspondence: Muhammed Keskin, University of Health Sciences Turkey, İstanbul Sultan 2. Abdülhamid Han Training and Research Hospital,

Department of Cardiology, istanbul, Turkey

Phone: +90 2165422020 E-mail: drmuhammedkeskin@gmail.com ORCID ID: orcid.org/0000-0002-4938-0097

Received: 26.07.2020 Accepted: 17.08.2020 
members suspected that she could have inhaled bleacher during the cleaning. Her past medical history was significant with newly diagnosed hypertension without additional cardiovascular risk factor. She was admitted to our ED with hypertensive urgency three months earlier, in which she was diagnosed with hypertension and treated as outpatient with oral antihypertensive drugs. She was prescribed metoprolol $50 \mathrm{mg}$ once daily and quinapril + hydrochlorothiazide 20/25 $\mathrm{mg}$ once daily. At physical examination, she had a systolic BP of $80 \mathrm{mmHg}$ and diastolic BP of $40 \mathrm{mmHg}$. Her heart rate was $109 \mathrm{bpm}$, temperature was $37.9^{\circ} \mathrm{C}$ and respiratory rate was 19. Her electrocardiogram showed sinus tachycardia with ST segment depression in DI, AVL, V5 and V6. Her Glascow Coma score was 14 with loss of orientation to time, place, and person. She had a troponin I level of $431 \mathrm{pg} / \mathrm{mL}$ (0-11.6) without any abnormalities in complete blood count and biochemistry parameters. The bedside transthoracic echocardiogram showed flap images within the ascending aorta and pericardial effusion. The computerized tomography (CT) of the thorax revealed that ascending aorta dimension was in normal range $(39 \mathrm{~mm})$ and confirmed dissection flap in the ascending aorta (Figure 1A). The sagittal view of the $\mathrm{CT}$ showed dissection flap in aortic arc and extending hematoma to the thoracic aorta (Figure 1B). The transverse view of the CT showed a hypertrophic left ventricle with a posterior wall of $23 \mathrm{~mm}$ in diameter and an interventricular septum of $21 \mathrm{~mm}$ in diameter (Figure 1C). Besides, there was an effusion of $20 \mathrm{~mm}$ in diameter in the pericardium compressing to the right ventricle (Figure 1C). Unhappily, the patient died while being transferred for surgery.

\section{Discussion}

Chronic hypertension, in other words "the silent killer", is mainly asymptomatic. An acute symptomatic elevation in BP is referred to as hypertensive crisis which covers hypertensive emergency, hypertensive urgency and asymptomatic hypertension (10). Togetherness of high BP and symptoms of end-organ damage (headache, blurry vision, chest pain, shortness of breath, altered mental status, epistaxis, and oliguria) is called hypertensive emergency and requires immediate treatment (10). On the other hand, hypertensive urgency is defined as having a $B P \geqslant 180 / 110 \mathrm{mmHg}$ without end-organ damage.

It was estimated that 8 million hospitalization and 20 million visits to ED are because of an acute hypertensive episode (11). Most of the cases are treated and released on the same day while some of them require more attention (12). Our case presented with hypertensive urgency three months earlier and was treated and released since there were no end-organ damage signs. Oral treatment was prescribed; cardiology and internal medicine examinations were advised. However, the patient could not follow the suggestions. Unfortunately, she presented with a life-threatening complication of hypertension, AD.

The morphology of $A D$ is the delamination of the vessel wall starting from an "intimal tear" and formation of a "false lumen". However, the intimal tear could extend to the adventitia resulting in blood extravasation to a cavity (pericardial, pleural, or abdominal cavity). Although the main mechanism is yet to be described, a two-stage approach could be applied to make it lighten: medial degeneration

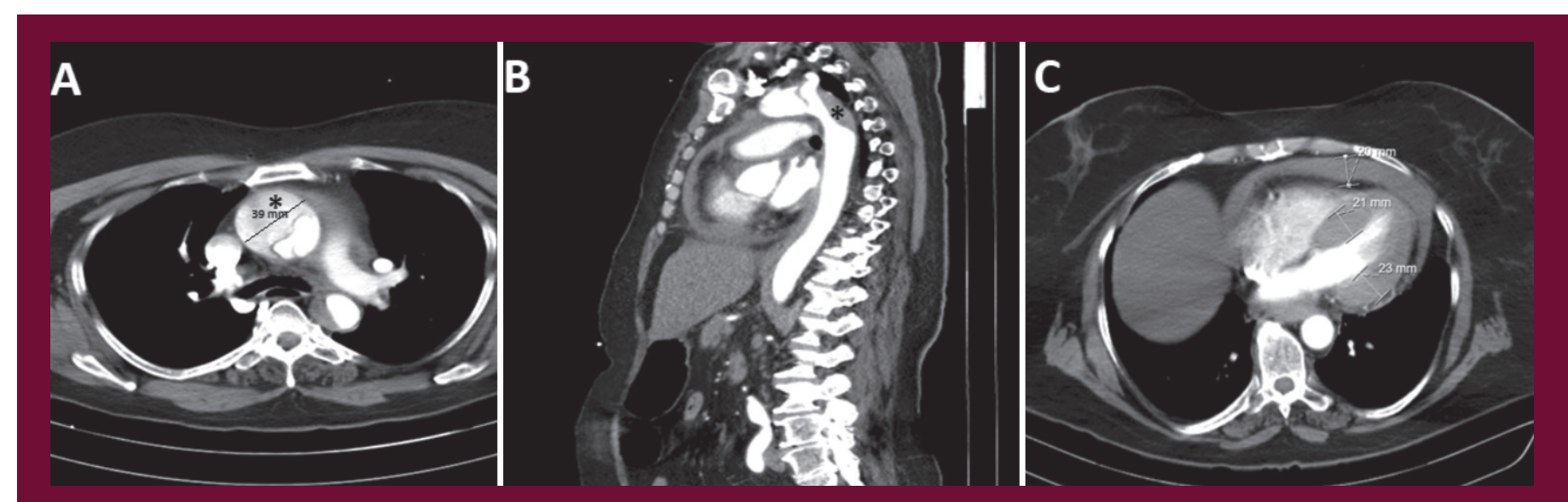

Figure 1. A) Thorax CT revealed that ascending aorta dimension was in normal range $(39 \mathrm{~mm})$ and confirmed dissection flap in the ascending aorta. The sagittal view of the CT showed dissection flap in aortic arc and extending hematoma (asterix) to the thoracic aorta. B) The sagittal view of the CT showed dissection flap in aortic arc and extending hematoma (asterix) to the thoracic aorta. C) The transverse view of the CT showed a hypertrophic left ventricle with a posterior wall of $23 \mathrm{~mm}$ in diameter and an interventricular septum of $21 \mathrm{~mm}$ in diameter. Besides, there was an effusion of $20 \mathrm{~mm}$ in diameter in the pericardium compressing to the right ventricle CT: Computerized tomography 
and mechanical wall stress. In Marfan syndrome and Vascular type Ehlers-Danlos syndrome, loss of elastic fibers and interconnecting elastic fibers cause medial aortic degeneration (13). The blood flow is presumed to be the trigger leading the "intimal tear" by producing shear stress on the aortic wall. Hypertension is present as a risk factor for $A D$ in $50-86 \%$ of the cases $(14,15,16)$. By decreasing blood flow of the vasa vasorum that nourishes one-third of the external aortic media, hypertension causes ischemia and damage and decreases elasticity (17). Besides, it acts as the "trigger" for entry site by increasing mechanical wall stress.

Our case was alone in terms of the AD in her family. None of her family members has aortic aneurysm and/or diagnosed with connective tissue disorders. Based on the CT findings, it could be assumed that she had an uncontrolled hypertension for a long time because her left ventricle wall thickens was $23 \mathrm{~mm}$. AD might prove the serious side effect of uncontrolled hypertension despite a normal aortic dimension in this case.

\section{Ethics}

Informed Consent: The patient's relatives gave consent for this case report.

Peer-review: Externally peer-reviewed.

\section{Authorship Contributions}

Surgical and Medical Practices:A.K., M.K., G.C., C.Ö., O.K., Concept: A.K., M.K., G.C., C.Ö., O.K., Design: A.K., M.K., G.C., C.Ö., O.K., Data Collection or Processing: A.K., Literature Search: A.K., M.K., G.C., C.Ö., O.K., Writing: A.K., M.K., G.C., C.Ö., O.K.

Conflict of Interest: No conflict of interest was declared by the authors.

Financial Disclosure: The authors declared that this study received no financial support.

\section{References}

1. Chow CK, Teo KK, Rangarajan S, Islam S, Gupta R, Avezum A, et al. PURE Study Investigators. Prevalence, awareness, treatment, and control of hypertension in rural and urban communities in high-, middle-, and lowincome countries. JAMA. 2013;310:959-968. [Crossref]

2. Lewington S, Clarke R, Qizilbash N, Peto R, Collins R, Prospective Studies Collaboration. Age-specific relevance of usual blood pressure to vascular mortality: a meta-analysis of individual data for one million adults in 61 prospective studies. Lancet. 2002;360:1903-1913. [Crossref]
3. Devereux RB, Alderman MH. Role of preclinical cardiovascular disease in the evolution from risk factor exposure to development of morbid events. Circulation. 1993;88:1444-1455. [Crossref]

4. Lonnebakken MT, Izzo R, Mancusi C, Gerdts E, Losi MA, Canciello G, et al. Left ventricular hypertrophy regression during antihypertensive treatment in an outpatient clinic (the Campania Salute Network). J Am Heart Assoc. 2017;6:e004152. [Crossref]

5. Kouchoukos NT, Dougenis D. Surgery of the thoracic aorta. N Engl J Med. 1997;336:1876-1889. [Crossref]

6. Meszaros I,Morocz J,Szlavi J,Schmidt J,Tornoci L,Nagy L,et al. Epidemiology and clinicopathology of aortic dissection. Chest. 2000;117:1271-1278. [Crossref]

7. Hagan PG, Nienaber CA, Isselbacher EM, Bruchman D, Karavite DJ, Russman $\mathrm{PL}$, et al. The International Registry of Acute Aortic Dissection (IRAD): New insights into an old disease. JAMA. 2000;283:897-903. [Crossref]

8. Varon J, Marik PE. The diagnosis and management of hypertensive crises. Chest. 2000;118:214-227. [Crossref]

9. Mehta RH, Suzuki T, Hagan PG, Bossone E, Gilon D, Llovet A, et al. Predicting death in patients with acute type a aortic dissection. Circulation. 2002;105:200-206. [Crossref]

10. Marik PE,Varon J. Hypertensive crises: challenges and management. Chest. 2007;131:1949-1962. [Crossref]

11. Owens PL, Mutter R. Statistical brief \#100: Emergency department visits for adults in community hospitals, 2008. Agency for Healthcare Research and Quality. Available from: http://www.hcup-us.ahrq.gov/reports/ statbriefs/sb100.pdf (Accessed January 19, 2018) [Link]

12. American Heart Association. High blood pressure ER visits jumped 25 percent between 2006 to 2011. Available from: https://newsarchive heart.org/high-blood-pressure-er-visits-jumped-25-percent-between2006-to-2011/\#: : :text=Researchers\%20collected\%20data\%20on\%20 about,patients\%20fell\%20by\%2015\%20percent. (Accessed January 19, 2018) [Link]

13. Akutsu K. Etiology of aortic dissection. Gen Thorac Cardiovasc Surg. 2019;67:271-276. [Crossref]

14. Suzuki T, Isselbacher EM, Nienaber CA, Pyeritz RE, Eagle KA, Tsai TT, et al. Type-selective benefits of medications in treatment of acute aortic dissection (from the international registry of acute aortic dissection [IRAD]). Am J Cardiol. 2012;109:122-127. [Crossref]

15. Li Y, Yang N, Duan W, Liu S, Yu S, Yi D. Acute aortic dissection in China. Am J Cardiol. 2012;110:1056-1061. [Crossref]

16. Howard DP, Banerjee A, Fairhead JF, Perkins J, Silver LE, Rothwell PM, et at. Population-based study of incidence and outcome of acute aortic dissection and premorbid risk factor control: 10-year results from the Oxford Vascular Study. Circulation. 2013;127:2031-2037. [Crossref]

17. Angouras D, Sokolis DP, Dosios T, Kostomitsopoulos N, Boudoulas $H$, Skalkeas G, et al. Effect of impaired vasa vasorum flow on the structure and mechanics of the thoracic aorta: implications for the pathogenesis of aortic dissection. Eur J Cardiothorac Surg. 2000;17:468-473. [Crossref] 